\title{
DOES SUKUK, DOMESTIC INVESTMENT, FOREIGN INVESTMENT, AND INFLATION CONTRIBUTE TO ECONOMIC GROWTH IN INDONESIA?
}

\section{APAKAH SUKUK, INVESTASI DALAM NEGERI, INVESTASI LUAR NEGERI, DAN INFLASI BERKONTRIBUSI PADA PERTUMBUHAN EKONOMI INDONESIA?}

\author{
Laela Setianingsih, Emy Widyastuti \\ Department of Sharia Economics - Faculty of Economics and Islamic Business - \\ Salatiga State Islamic Institute \\ laelasetianingsih@gmail.com*, emywidyastuti@iainsalatiga.ac.id
}

\begin{abstract}
ABSTRAK
Indikator yang menentukan keberhasilan pembangunan ekonomi adalah pertumbuhan ekonomi. Kemajuan dan kesejahteraan suatu negara dapat dilihat melalui pertumbuhan ekonominya. Pertumbuhan ekonomi Indonesia berfluktuasi setiap tahun dan dipengaruhi oleh banyak faktor. Penelitian ini bertujuan untuk mengetahui kontribusi sukuk jangka pendek dan jangka panjang, penanaman modal dalam negeri, penanaman modal asing, dan inflasi terhadap pertumbuhan ekonomi di Indonesia dari tahun 2011 hingga 2019. Metode yang digunakan dalam penelitian ini adalah Vector Error Correction Model (VECM). Data yang digunakan dalam penelitian ini adalah data sekunder time series dengan periode penelitian triwulanan dari tahun 2011 hingga 2019. Hasil pengujian menunjukkan bahwa variabel sukuk memiliki kontribusi negatif yang tidak signifikan terhadap pertumbuhan ekonomi dalam jangka pendek dan dalam jangka Panjang, sukuk berpengaruh positif signifikan terhadap pertumbuhan ekonomi. Variabel investasi dalam negeri dalam jangka pendek dan jangka panjang memberikan kontribusi positif terhadap pertumbuhan ekonomi. Variabel investasi dalam negeri jangka pendek dan jangka panjang memberikan kontribusi positif yang tidak signifikan terhadap pertumbuhan ekonomi. Dan variabel inflasi memiliki kontribusi yang negatif dan tidak signifikan terhadap pertumbuhan ekonomi dalam jangka pendek dan jangka panjang.
\end{abstract}

Kata Kunci: Sukuk, Penanaman Modal Dalam Negeri, Penanaman Modal Asing, Inflasi, Pertumbuhan Ekonomi.

\begin{abstract}
The indicator for determining the success of economic development is economic growth. The progress and welfare of a country can be seen through its economic growth. Indonesia's economic growth fluctuates every year and is influenced by many factors. This study aims to determine the short-term and long-term contributions of Sukuk, domestic investment, foreign investment, and inflation to economic growth in Indonesia from 2011 to 2019. This method used in this research is the Vector Error Correction Model (VECM). The data used in this study are secondary time series data with a quarterly research period from 2011 to 2019. The test results show that the sukuk variable has an insignificant negative contribution to economic growth in the short term and the long term sukuk has a significant positive contribution to economic growth. Domestic investment variables in the short and long term contribute positively to economic growth. The short-term and long-term domestic investment variables have an insignificant positive contribution to economic growth. And the inflation
\end{abstract}

Informasi artikel

Diterima: 25-1 1-2020

Direview: 04-12-2020

Diterbitkan: 26-12-2020

*Korespondensi

(Correspondence):

Laela Setianingsih

Open access under Creative Commons Attribution-Non

Commercial-Share A like 4.0 International Licence

(CC-BY-NC-SA) (c) (1) () 
Setianingsih, et al/Jurnal Ekonomi Syariah Teori dan Terapan Vol. 7 No. 12 Desember 2020: 2375-2384

variable has a negative and insignificant contribution to economic growth in the short and long term.

\section{Keywords: Sukuk, Domestic Investment, Foreign Investment,} Inflation, Economic Growth.

\section{INTRODUCTION}

Economic development is a change that is carried out continuously to improve the standard of living and welfare of society fairly and equitable manner. The benchmark for determining the success of economic development is economic growth. Therefore, development in developing countries must be improved to increase economic growth in a country. The role of the government is expected to make a plan for economic growth so that economic growth in a country increases and also the welfare of citizens are increases. Economic growth is measured using the Gross Domestic Product (GDP) data, namely through total income and total expenditure of everyone in the economy (Mankiw, 2007).

In Islamic economics, one of the factors that drive economic growth is sukuk. The more development of the Islamic economic system in each country encourages citizens to carry out economic activities in accordance with Islamic principles. Sukuk is a new form of financing that is developing in line with the development of the Islamic economy(Datuk, 2014). Sukuk is an investment instrument intended for development in the real sector.

In addition, investments that encourage economic growth are Domestic Investment and Foreign
Investment. Domestic investment is needed to reduce dependence on foreign products, while foreign investment is needed to help create jobs, update technology and assist in industrialization. Domestic and foreign investment is one of the variables in the calculation of national income which is the benchmark for economic growth in each country.

Apart from investment, inflation can also affect economic growth. Inflation is an indicator used to measure economic stability in a country. Every country has experienced inflation in its economy. Inflation is an economic phenomenon that is difficult to avoid. Inflation can have both a good and a bad impact on the economy. To find out whether inflation is good or bad for the economy, it can be seen from the amount of inflation per year in each country. In Indonesia sukuk, domestic investment, foreign investment, inflation, and economic growth show fluctuating figures every year.

Table 1.

Data of Economic Growth, Sukuk, Domestic Investment, Foreign Investment, and Inflation in 2011 -

\begin{tabular}{|c|c|c|c|c|c|}
\hline \multicolumn{6}{|c|}{2019} \\
\hline $\begin{array}{l}\text { Ye } \\
\text { ar }\end{array}$ & $\begin{array}{c}\text { PDB } \\
\text { (Billio } \\
n \\
\text { Rupia } \\
\text { h) }\end{array}$ & $\begin{array}{l}\text { Outstandin } \\
\text { gSukuk } \\
\text { (Billion } \\
\text { Rupiah) }\end{array}$ & $\begin{array}{c}\text { Dome } \\
\text { stic } \\
\text { Invest } \\
\text { ment } \\
\text { (Trillion } \\
\text { ) }\end{array}$ & $\begin{array}{c}\text { Foreig } \\
n \\
\text { Invest } \\
\text { ment } \\
\text { (Trillion } \\
\text { ) }\end{array}$ & $\begin{array}{c}\text { Inflasi } \\
\text { (Perc } \\
\text { ent) }\end{array}$ \\
\hline $\begin{array}{l}20 \\
11 \\
\end{array}$ & $\begin{array}{c}7,287 . \\
64\end{array}$ & 5.88 & 76.00 & 175.30 & 3.79 \\
\hline $\begin{array}{l}20 \\
12\end{array}$ & $\begin{array}{c}7,727 \\
10\end{array}$ & 6.88 & 92.20 & 221.00 & 4.30 \\
\hline $\begin{array}{l}20 \\
13\end{array}$ & $\begin{array}{c}8,156 . \\
51\end{array}$ & 7.55 & 128.20 & 270.40 & 8.38 \\
\hline $\begin{array}{l}20 \\
14 \\
\end{array}$ & $\begin{array}{c}8,564 . \\
87\end{array}$ & 7.11 & 156.10 & 307.00 & 8.36 \\
\hline
\end{tabular}


Setianingsih, et al/Jurnal Ekonomi Syariah Teori dan Terapan Vol. 7 No. 12 Desember 2020: 2375-2384

\begin{tabular}{|c|c|c|c|c|c|}
\begin{tabular}{|c|c|c|c|}
20 \\
15
\end{tabular} & $\begin{array}{c}8,982 . \\
52\end{array}$ & 9.90 & 179.50 & 365.90 & 3.35 \\
\hline 20 & $9,434$. & & & & \\
16 & 61 & 11.88 & 216.50 & 396.50 & 3.02 \\
\hline 20 & $9,912$. & & & & \\
17 & 93 & 15.74 & 262.30 & 430.50 & 3.61 \\
\hline 20 & 10,42 & & & & \\
18 & 5.40 & 21.30 & 328.60 & 392.70 & 3.13 \\
\hline 20 & 10,94 & & & & \\
19 & 9.24 & 29.83 & 386.50 & 423.10 & 2.72 \\
\hline \multicolumn{5}{|c|}{ Source: processed data, 2020} &
\end{tabular}

Based on table 1, economic growth from 2011-2019 continues to increase. Economic growth in 2019 reached 10,949.24 billion rupiahs. Sukuk and domestic investment have also increased every year. Sukuk in 2019 reached 29.83 billion rupiahs. Domestic investment in 2019 reached 386.50 trillion. Foreign investment in 2018 has decreased by 37.80 trillion and in 2019 foreign investment has increased. Meanwhile, inflation has fluctuated every year. The highest inflation in 2013 was $8.38 \%$ and the lowest inflation in 2019 was $2.72 \%$.

This study aims to determine the short-term and long-term contributions between sukuk, domestic investment, foreign investment, and inflation to economic growth in Indonesia in 20112019.

\section{THEORETICAL FRAMEWORK}

\section{Economic growth}

Economic growth describes an increase in the standard of living as measured by real output per person ( $M$. Wijaya, 1999). The Harrod-Domar theory of economic growth states that to increase economic growth in a country it is necessary to form capital as an additional stock of capital. According to NeoClassical theory, economic growth depends on the development of production factors, namely: population, capital, labor, and technology(Jonaidi, 2012). Capital formation is obtained from savings as an additional stock of national capital. The higher income is saved, so it will increase the national investment.

High economic growth will encourage the continuity of economic development and increase the welfare of a country. The population has increased every year, daily needs are also increasing, so additional income is needed every year. An increase in income can be achieved by an increase in aggregate output or gross domestic product (GDP) (Syamsul\& Soesatyo, 2020).

\section{Sukuk}

Sukuk is the plural form of the word sack which comes from Arabic which means documents, securities, deeds, and checks (Soemitra, 2014). According to Fatwa DSN-MUI Number 32 / DSN-MUI / IX / 2002 concerning Islamic bonds, namely long-term securities based on sharia principles issued by issuers of Islamic bondholders which oblige the issuer to pay income to Islamic bondholders in the form of profit-sharing or margin or fee(Faniyah, 2018). The sukuk instruments used in Indonesia are sukuk mudharabah and sukuk ijarah. According to the issuer, sukuk in Indonesia is divided into two, namely sukuk issued by the government or retail sukuk and sukuk issued by companies or corporate sukuk (Faiza \& Shafiyatun, 2018). 
Setianingsih, et al/Jurnal Ekonomi Syariah Teori dan Terapan Vol. 7 No. 12 Desember 2020: 2375-2384

\section{Domestic investment}

Based on Law No. 25 of 2007, Domestic Investment is an activity of investing to conduct business in the territory of the Republic of Indonesia which is carried out by domestic investors. There are several forms of domestic investment, as follows (1) direct domestic investment, namely investment made by the owner of the capital itself. (2) Indirect domestic investors, namely domestic investors who invest in bonds or government securities(Aulia, 2018).

\section{Foreign investment}

Robert Solow's investment theory explains that investment, workforce growth, and technological development are factors that affect economic growth in a country. The investment that comes from within the country and abroad can help a country's economy (Cahyono \& Putri, 2017).

Based on Law No. 25 of 2007, foreign investment is an activity of investing to conduct business in the territory of the Republic of Indonesia. This investment is carried out by foreign nationals, either using the full capital or joining forces with domestic investors. Foreign capital that is commonly used is the foreign direct investment (FDI). Foreign Investment is the entry of foreign capital into Indonesia in physical forms, such as factory construction(Jened, 2016). The objectives of foreign investment are resource seeking FDI, market seeking FDI, efficiency-seeking FDI, strategic asset seeking FDI (Rahmah, 2020).

\section{Inflation}

The definition of inflation in an estimation that was popularized in the dictionary al-Munawwiris Ta'dakhum Mal or tadakhum al-As'ar. Literally, al means big. In terminology, inflation is a price increase that occurs continuously (Aji \& Mukri, 2020). Inflation is an increase in the general price level of goods or service commodities during a certain period(Adiwarman, 2017). In Islamic economics, inflation consists of Natural Inflation (naturally) and Human Error Inflation (man-made). According to inflation is caused by two things, it is demand-pull inflation and cost-push inflation. Inflation is caused by a pull in demand due to an increase in total demand in a situation of full employment. On other hand, inflation is caused by cost pressures due to production shortages such as natural disasters, weather, raw materials, and speculation (Islamiah, 2015).

\section{RESEARCH METHODS}

\section{Types of Data Sources}

The type of research used in this research is quantitative research. Quantitative research is research that is measured in numbers. The data in this study are secondary, taken through data reports published by related institutions.

Sukuk data is taken through the website of the Financial Services Authority (OJK), Domestic Investment and Foreign Investment are retrieved through the website of the Investment Coordinating Board (BKPM), inflation is taken from Bank 
Setianingsih, et al/Jurnal Ekonomi Syariah Teori dan Terapan Vol. 7 No. 12 Desember 2020: 2375-2384

Indonesia website, and Economic Growth is retrieved through the website of the Central Statistics Agency (BPS). The period used is quarter 2011-2019.

\section{Population and Sample}

The population in this study are Sukuk, domestic Investment, foreign Investment, Inflation and Economic Growth in Indonesia. The sample in this study are Sukuk, domestic Investment, foreign Investment, Inflation and Economic Growth in Indonesia in 2011-2019.

\section{Analysis Technique}

This study used quantitative data which is applied using the vector error correction model (VECM). The vector error correction model is used to explain the short and long-term relationships between variables. The vector error correction model is a model derived from the vector autoregression analysis model so that the assumptions used in the vector error correction model are the same as used in the vector autoregression model. According to Gujarati in Akbar (2018), the advantage of using this model is that it can analyze economic phenomena in the short and long term and can solve problems regarding time-series data that are not stationary and spurious regression. The vector error correction model can be formulated as follows:

$\Delta \mathrm{y}_{\mathrm{t}}=\mu_{0 \mathrm{x}}+\mu_{1 \mathrm{x}} \dagger+\Pi_{\mathrm{x}} \mathrm{y}_{\mathrm{t}-1}+\sum_{i=1}^{k-1} r_{\mathrm{ix}} \Delta \mathrm{y}_{\mathrm{t}-1}+\epsilon_{\dagger}$

Where:

$y^{\dagger}=$ vector which contains the variables analyzed in the study

Hox $=$ intercept vector

$\mu_{1 \times}=$ regression coefficient vector

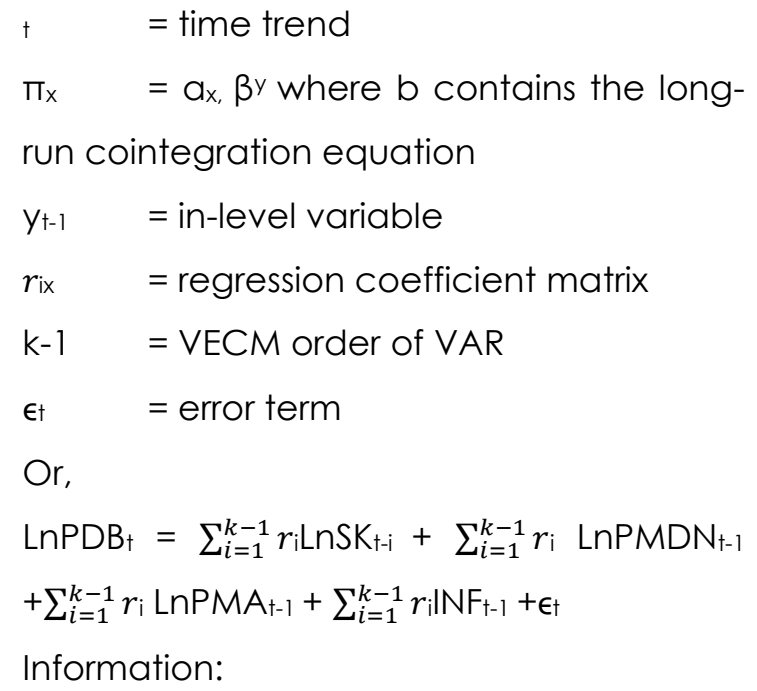

$\mathrm{LnPDB}_{\dagger}=$ natural logarithm of economic growth $\uparrow$ period

LnSK ${ }_{\dagger}=$ natural logarithm of sukuk $\dagger$ period

$\operatorname{LnPMDN}_{\dagger}=$ natural logarithm of domestic investment $\dagger$ period

$\operatorname{LnPMA}_{\dagger}=$ natural logarithm of foreign investment period $\dagger$

$\mathrm{INF}_{\dagger} \quad=$ Inflation $\mathrm{t}$ period

The analytical tool used in this research is using eviews 9. The following are the assumptions in the vector error correction model test:

\section{Stationarity test}

The method of determining the stationarity test is by using the Augmented Dickey-Fuller method with the criteria if the probability value is $<0.05$ then the data is said to be stationary, and if the probability value is $>0.05$ then the data is not stationary.

\section{Optimal lag test}

In determining the optimal lag length through Aike Information Criterion (AIC), Schwarz Information Criterion (SIC), and Hannan-Quinn (HQ). The optimal lag 
Setianingsih, et al/Jurnal Ekonomi Syariah Teori dan Terapan Vol. 7 No. 12 Desember 2020: 2375-2384

test is obtained by selecting the lag with the most $(*)$ sign.

\section{Granger Causality test}

The Granger causality test is used to determine a two-way relationship with a significance level of $1 \%$ to $5 \%$. The determination of this test can be seen through the probability value of the two variables. If the probability value is less than the significance level, there is a twoway relationship. And vice versa.

\section{Cointegration test}

The cointegration test was tested using the Engle-Granger and the Johansen test. This test aims to determine the long-term balance of the independent and dependent variables.

\section{VAR Stability test}

The VAR stability test aims to determine whether the VAR estimate is stable or not. This test is carried out by looking at the modulus value, if the modulus value is $<1$ then the data is said to be stable so that the IRF FEVD tests are considered valid.

\section{VECM Estimation test}

VECM estimation test to determine short-term and long-term relationships. The variable is said to be influential if the tstatistic value $>$ t-table.

\section{Impulse Response Function (IRF) Test}

IRF can describe how long the effect of a variable shock on other variables during a certain period of time.

\section{Forecast Error Variance Decomposition (FEVD) Test}

FEVD is used to explain the contribution of each variable in the future period and is measured in the form of a percentage.

\section{RESULTS AND DISCUSSION}

\section{Stationarity Test Results}

Based on the results of the unit root test, it can be seen that if the value of prob. $<0.05$ then the data is said to be stationary, and if the value is prob. $>0.05$ then the data is not stationary.

Table 2.

Unit Root Test Result

\begin{tabular}{|c|l|c|c|}
\hline \multirow{4}{*}{ Difference } & \multicolumn{2}{|c|}{ Variable } & \multicolumn{2}{c|}{ Unit Root Test } \\
\cline { 3 - 4 } & & ADF & Prob \\
\hline \multirow{4}{*}{ Level } & GDP & -1.398 & 0.570 \\
\cline { 2 - 4 } & SK & 2.036 & 0.999 \\
\cline { 2 - 4 } & PMDN & -0.865 & 0.786 \\
\cline { 2 - 4 } & PMA & -2.826 & 0.065 \\
\cline { 2 - 4 } & INF & -0.833 & 0.796 \\
\hline \multirow{5}{*}{ Difference } & GDP & -13.151 & 0.000 \\
\cline { 2 - 4 } & SK & -4.494 & 0.001 \\
\cline { 2 - 4 } & PMDN & -7.078 & 0.000 \\
\cline { 2 - 4 } & PMA & -1.504 & 0.517 \\
\cline { 2 - 4 } & INF & -4.072 & 0.004 \\
\hline \multirow{4}{*}{ 2nd } & GDP & $-8,255$ & 0.000 \\
\cline { 2 - 4 } Difference & SK & $-3,379$ & 0.022 \\
\cline { 2 - 4 } & PMDN & $-4,902$ & 0.001 \\
\cline { 2 - 4 } & PMA & $-3,543$ & 0.025 \\
\cline { 2 - 4 } & INF & $-3,745$ & 0.009 \\
\hline
\end{tabular}

Source: processed data, 2020

From table 2, it can be concluded that the data is stationary at the level of 2 nd difference.

\section{Optimal lag test results}

The results of the optimal lag test indicate that the lag in this study is lag 3. This result is obtained by selecting the lag with the most $(*)$ sign.

Table 3.

Lag optimal test result

\begin{tabular}{|c|c|c|c|c|c|}
\multicolumn{7}{c|}{ Lag optimal test result } \\
\hline Lag & LR & FPE & AIC & SC & HQ \\
\hline 0 & NA & $1.54 \mathrm{E}-10$ & -8.407 & $-8.178^{*}$ & -8.331 \\
\hline 1 & 20.446 & $3.42 \mathrm{E}-10$ & -7.631 & -6.256 & -7.175 \\
\hline 2 & $67.866^{*}$ & $7.28 \mathrm{E}-11$ & -9.300 & -6.781 & -8.465 \\
\hline & & $5.43 \mathrm{e}-$ & - & & \\
3 & 35.243 & $11^{*}$ & $9.940^{*}$ & -6.276 & $-8.725^{*}$ \\
\hline
\end{tabular}

\section{Granger Causality Test Results}

From the results of the Granger test, it can be seen that the variable that has a 
Setianingsih, et al/Jurnal Ekonomi Syariah Teori dan Terapan Vol. 7 No. 12 Desember 2020: 2375-2384

causal relationship (two directions) is the variable with the prob value. $<0.05$ and vice versa, if the value of prob. $>0.05$, the variable does not have a causal relationship.

The results of the Granger test between the sukuk variable and economic growth show that there is no causal relationship between variables. The probability value of sukuk on economic growth is $0.664>0.05$ and the probability value of economic growth for sukuk is $0.586>0.05$. The probability value of PMDN on economic growth is $0.275>0.05$ and the economic growth for domestic Investment is $0.002<0.05$. So, it can be concluded that domestic Investment and economic growth have a one-way relationship.

The foreign Investment variable and economic growth do not have a causal relationship indicated by the probability value equal to 0.763 and $0.978>0.05$. The variables of inflation and economic growth indicate that there is no causal relationship between variables. The probability value of inflation on economic growth is $0.798>0.05$ and the probability value of economic growth for sukuk is $0.479>0.05$.

\section{Cointegration Test Results}

The cointegration test was tested using the Engle-Granger and the Johansen test.

Table 4.

Cointegration Results

\begin{tabular}{|c|c|c|}
\hline $\begin{array}{c}\text { Hypothesized No. of } \\
\text { CE (s) }\end{array}$ & $\begin{array}{c}\text { Trace } \\
\text { Statistics }\end{array}$ & $\begin{array}{c}0.05 \text { Critical } \\
\text { Value }\end{array}$ \\
\hline None $^{*}$ & 117,582 & 69,819 \\
\hline At most $1^{*}$ & 71,799 & 47,856 \\
\hline
\end{tabular}

\begin{tabular}{|c|c|c|}
\hline At most 2 $^{*}$ & 39,914 & 29,797 \\
\hline At most 3 & 16,488 & 15,495 \\
\hline At most 4 & 1,256 & 3,841 \\
\hline
\end{tabular}

Source: processed data, 2020

From the results of the cointegration test, it can be concluded that sukuk, domestic Investment, foreign Investment, and inflation on economic growth indicate a long-term relationship. This result can be seen from the trace statistic> critical value.

\section{VAR Stability Test Results}

Based on the results of the stability test, it can be concluded that the variables of sukuk, domestic Investment, foreign Investment, and inflation on economic growth have a value of less than one. So that the model used has model stability.

Table 5.

VAR stability test results

\begin{tabular}{|c|c|}
\hline Root & Modulus \\
\hline $0.002557-0.983052 i$ & 0.983 \\
\hline $0.002557+0.983052 i$ & 0.983 \\
\hline$-0.453452-0.632221 i$ & 0.778 \\
\hline$-0.453452+0.632221 i$ & 0.778 \\
\hline$-0.754944-0.103132 i$ & 0.762 \\
\hline$-0.754944+0.103132 i$ & 0.762 \\
\hline$-0.008341-0.750367 i$ & 0.750 \\
\hline$-0.008341+0.750367 i$ & 0.750 \\
\hline $0.672948-0.080832 i$ & 0.678 \\
\hline $0.672948+0.080832 i$ & 0.678 \\
\hline$-0.545542-0.366532 i$ & 0.657 \\
\hline$-0.545542+0.366532 i$ & 0.657 \\
\hline $0.217518-0.603360 \mathrm{i}$ & 0.641 \\
\hline $0.217518+0.603360 \mathrm{i}$ & 0.641 \\
\hline 0.167539 & 0.168 \\
\hline
\end{tabular}

Source: processed data 2020

\section{VECM Estimation Test Results}

Based on the results of the vector error correction model estimation test, it can be concluded that in the short term of the sukuk variable has a significant negative contribution to economic growth. Domestic Investment and foreign investment variables have an insignificant 
Setianingsih, et al/Jurnal Ekonomi Syariah Teori dan Terapan Vol. 7 No. 12 Desember 2020: 2375-2384

positive contribution to economic growth. Meanwhile, the inflation variable has an insignificant negative contribution to economic growth.

In the long term, the sukuk variable has a positive contribution not significant to economic growth with a coefficient of 0.020. The results of this study are compatible with Nurafiati (2019), if the sukuk has increased by $1 \%$ it will increase economic growth by $0.020 \%$. When sukuk has increased it will help in the real sector so that the development of state projects can be increased and will give an impact on increasing economic growth.

The domestic Investment variable has a significant positive contribution to economic growth with a coefficient of 0.584. The results of this study are compatible with research conducted by Asnawi (2011). If domestic Investment increases by $1 \%$, economic growth will increase by $0.584 \%$. Increasing domestic capital can help create new jobs. In addition, domestic capital can assist the government in achieving development goals.

The foreign Investment variable has an insignificant positive contribution to economic growth with a coefficient of 0.069. This research is suitable with research Muazi and Arianti (2013) If foreign Investment increases by $1 \%$, economic growth will increase by $0.069 \%$. Foreign capital is expected by every country to help increase economic growth. Foreign capital aims to reduce the government's foreign debt. The presence of foreign capital can increase employment and technology transfer.

Meanwhile, the inflation variable has a significant negative contribution to economic growth with a coefficient of 0.025 . If inflation increases by $1 \%$, it will reduce economic growth by $0.025 \%$. These results are compatible with research conducted by Ridlo and Setyani (2020), which stated that high inflation will be responded negatively by economic growth.

\section{Impulse Response Function (IRF) Test Results}

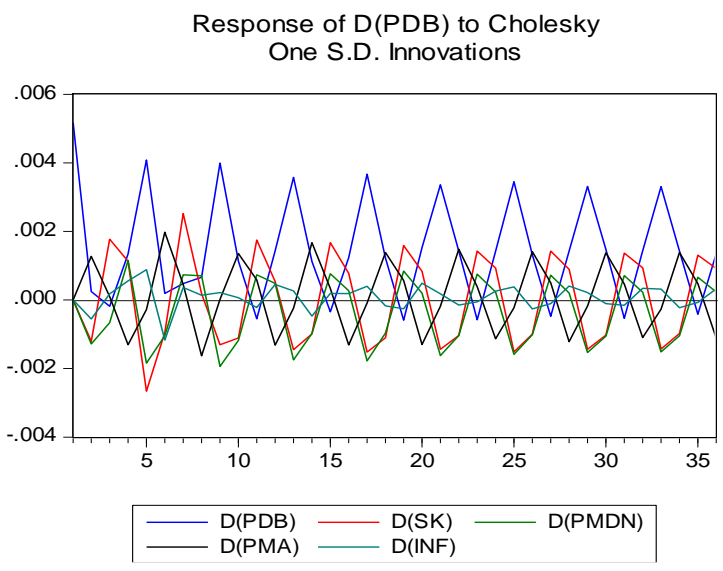

Source: processed data, 2020

$$
\text { Figure } 1 .
$$
IRF Test Results

Based on the results of the IRF test above, it can be seen that economic growth responds positively and negatively to shocks given by the variables of sukuk, domestic Investment, foreign Investment, and inflation.

\section{Forecast Error Variance Decomposition (FEVD) Test Results}

Based on the results of the FEVD test, it can be seen that the variable that has the largest contribution to economic growth is the variable of economic growth itself. Meanwhile, the independent 
Setianingsih, et al/Jurnal Ekonomi Syariah Teori dan Terapan Vol. 7 No. 12 Desember 2020: 2375-2384

variable gives a fluctuating contribution to the dependent variable.

Variance Decomposition of $\mathrm{D}(\mathrm{PDB})$

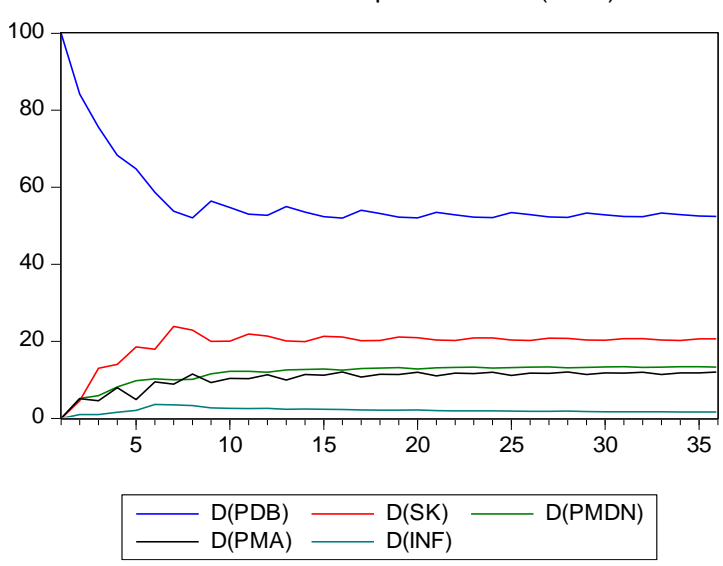

Source: processed data, 2020

Figure 2

FEVD Test Results

\section{CONCLUSION}

Based on the results of the analysis and discussion that has been described the contribution of sukuk, domestic Investment, foreign Investment, and inflation to economic growth in Indonesia in 2011-2019, it can be concluded that sukuk in the short term has a significant negative contribution to economic growth in Indonesia. Meanwhile, in the long term, sukuk will not make a significant positive contribution to economic growth. Domestic Investment has a positive contribution to economic growth in the short and long term. Foreign Investment in the short and long term has a positive contribution to economic growth in Indonesia. Meanwhile, inflation has a negative contribution to economic growth in Indonesia.

\section{BIBLIOGRAPHY}

Adiwarman, A. K. (2017). Islamic micro economics. Jakarta: Rajawali Pers.

Aji, A. M., \& Mukri, S. G. (2020). Monetary strategy based on sharia economy (Islamic efforts to overcome inflation). Yogyakarta: Deepublish.

Akbar, T. (2018). Analysis of the causality relationship between GDP, imports, FDI and foreign debt in Indonesia. Eksis, 13(2), 111-130.

Asnawi. (2011). Expenditure on development, investment, exports and economic growth in Aceh Province. Journal of Chemical Information and Modeling, 53(9), 26-28.

Aulia, S. (2018). Analysis of the influence of investment and labor on GDP growth in the manufacturing sector in DI Yogyakarta 1996-2016. Economics Islamic University of Indonesia.

Cahyono, H., \& Putri, S. A. (2017). The influence of PMDN, PMA and regional expenditure of East Java on economic growth in the city of Surabaya and Banyuwangi Regency. Media Trend: Periodic Economic Studies and Development Studies, 12(1), 63-75.

Datuk, B. (2014). Sukuk, new dimensions of government financing for economic growth. Journal of Accounting and Business Research, $14(1), 111-124$.

Faiza, N. A. R., \& Shafiyatun. (2018). The effect of the outstanding value of corporate sukuk on indonesia's gross domestic product (GDP) quarterly period 2011-2017. El-Qist: Journal of Islamic Economic and Business (JIEB), 08(01), 1577-1596.

Faniyah, I. (2018). Legal certainty of state sukuk as an investment instrument in Indonesia. Yogyakarta: Deepublish.

Islamiah, N. (2015). Analysis of the influence of development expenditure / capital and inflation rate on economic growth and tax revenue in Indonesia. Jurnal Economix, 3(1), 46-57.

Jened, R. (2016). Theory and policy of direct investment law (Direct investment). Jakarta: Kencana.

Jonaidi, A. (2012). Analysis of economic growth and poverty in Indonesia. Journal of Economic Studies, 1(1), 140-164.

M. Wijaya, F. (1999). Introduction to macroeconomics series. 
Setianingsih, et al/Jurnal Ekonomi Syariah Teori dan Terapan Vol. 7 No. 12 Desember 2020: 2375-2384

Yogyakarta: BPFE Yogyakarta.

Mankiw, G. N. (2007). Macroeconomics. Jakarta: Erlangga.

Muazi, N. M., \& Arianti, F. (2013). Analysis of the effect of foreign investment and domestic investment on economic growth in Central Java 1990-2010. Diponegoro Journal of Economics, 2(1), 1-9.

Nurafiati, N. (2019). The development of sharia capital market and its contribution to economic growth in Indonesia. Inclusive Journal: Journal of Islamic Economic and Law Research Studies, 4(1), 65-75.

Rahmah. (2020). Investment law. Jakarta:
Kencana.

Ridlo, M., \& Setyani, D. (2020). The effect of zakat, inflation and the development of micro, small and medium enterprises on economic growth in 2011-2018 (Case study in Indonesia). Journal of Ekombis, 6(1), 75-83.

Soemitra, A. (2014). The future of Islamic capital market in Indonesia. Jakarta: Kencana.

Syamsul, A., \& Soesatyo, Y. (2020). Economic growth, unemployment rate, and consumption, in the frame of community welfare. Semarang: CV. Pena Persada. 